\title{
Evaluation of Ethanolic Extract of Desmodium Gyrans DC Leaves on Wound Healing Activity in Rats
}

\author{
Gopalakrishnan S* and Rajameena R
}

Senior Professor and Head Department of Pharmaceutical Chemistry, Manonmaniam Sundaranar University, Tirunelveli, India

\begin{abstract}
Desmodium gyrans DC is a well-known herb for its antidote, cardiac-tonic and wound healing activities. The present study was aimed for wound healing potential of the ethanol extract of Desmodium gyrans leaves in the form of simple ointment using two types of wound models in rats, viz. excision wound and dead space wound. The results were comparable to standard drug ciphadin ointment, in terms of wound contraction, tensile strength, histopathological and hydroxy proline content. Histopathological study showed significant increase in fibroblast cells, collagen fibres and blood vessels formation. All parameters were observed significant $(p<0.01)$ in comparison to control group.
\end{abstract}

Keywords: Desmodium gyrans; Wound healing; Excision wound; Dead space wound; Histopathological; Fibroblast cells

\section{Introduction}

The world health organization (WHO) urged researchers to examine whether traditional medicines produced any beneficial clinical results [1]. The plant kingdom represents a largely unexplored reservoir of biologically active compounds not only as drugs, but also as unique templates that could serve as a starting point for synthetic analogs and an interesting tool that can be applied for a better understanding of biological processes. Folkloric uses are supported by a long history of human experience. Numerous biologically active plants are discovered by evaluation of ethnopharmacological data, and these plants may offer the local population immediately accessible therapeutic products [2].

Some of these plants are used in the management of fresh wounds, while others for the treatment chronic wounds. The common ways of the treatment are either direct application of crushed fresh plant on the wound or repeated wash of the wound with a plant decoction. Despite the wide spread use of local plants in wound healing, only few of them have been investigated for their potential usefulness using excision and incision wound models by rats $[3,4]$.

Wound healing involves continuous cell-cell and cell-matrix interactions that allow the process to proceed in three overlapping phase's viz. inflammation, cellular proliferation and remodeling.

Phase 1 is a coagulation and inflammatory phase (0-3 days) and this involves migration of neutrophils at margin of incision, moving towards the fibrin clot.

Phase 2 is a proliferative phase (3-12 days) in which the neutrophils are largely replaced by the macrophages. Granulation tissue progressively invades the incision space and the incisional space is filled with granulation tissue. Collagen fibrils become more abundant and begin to bridge the incision.

Phase 3 is a remodeling phase (3-6 months), involving continuous accumulation of collagen and proliferation of fibroblasts. There is marked reduction in leukocyte infiltration and edema. The phase involves synthesis of collagen fibers, leading to increase in tensile strength of the skin [5].

Reports about medicinal plants affecting various phases of the wound healing process, such as coagulation, inflammation, fibroplasia, collagenation, epithelization and wound contraction are abundant in the scientific literature [6-9]. Still, one should keep in mind that plants have not only beneficial effects in promoting the healing process of wounds and burns or protecting the skin from fungal and bacterial infection or anti-tumor activists against skin cancer, they can be involved in different allergic, photo allergic and irritant skin reactions [10].

Desmodium gyrans DC (Fam. Fabaceae) is commonly known as "Thozhukanni" in Tamil "Namaskari" in Sanskrit. Traditionally Desmodium gyrans DC is used as antidote, cardiac-tonic and wound healing drug. The genus, Desmodium, of the Fabaceae family, includes about 350 species distributed in tropical and subtropical zones worldwide; some of them can be used as herbal medicines. For example, Desmodium gangeticum has been demonstrated to possess antioxidant, anti-nociceptive, anti-inflammatory $[11,12]$, anti-emetic [13], cardio-protective [14], and anti-ulcer effects [15]. Phytochemical studies have progressively isolated gangetin [16], salicylic acid, rutin [17], Desmodin, gangetinin [18], chlorogenic acid and caffeic acid from Desmodium gangeticum [19]. Desmodium triflorum has been reported to possess antioxidant [20], analgesic and anti-inflammatory activities [21].

The present study was carried out to determine the effect of the ethanolic extract of Desmodium gyrans leaves on wound healing activity by excision and dead space wound healing models in rats.

\section{Material and Methods}

\section{Plant materials}

The plant was collected in the month of September from

*Corresponding author: Gopalakrishnan S, Senior Professor and Head Department of Pharmaceutical Chemistry, Manonmaniam Sundaranar University, Tirunelveli, India, Tel: 094431 72243; E-mail: sgkmsu@yahoo.co.in

Received July 26, 2012; Accepted September 20, 2012; Published September 25, 2012

Citation: Gopalakrishnan S, Rajameena R (2012) Evaluation of Ethanolic Extract of Desmodium Gyrans DC Leaves on Wound Healing Activity in Rats. Pharmaceut Anal Acta 3:169. doi:10.4172/2153-2435.1000169

Copyright: () 2012 Gopalakrishnan S, et al. This is an open-access article distributed under the terms of the Creative Commons Attribution License, which permits unrestricted use, distribution, and reproduction in any medium, provided the original author and source are credited. 
Citation: Gopalakrishnan S, Rajameena R (2012) Evaluation of Ethanolic Extract of Desmodium Gyrans DC Leaves on Wound Healing Activity in Rats. Pharmaceut Anal Acta 3:169. doi:10.4172/2153-2435.1000169

Page 2 of 5

Trivandrum, Kerala, India and was identified by Dr. V. Chelladurai, Research Officer (Botany). Central Council of Research in Ayurveda and Siddha, Government Siddha Medical College, Palayamkottai, Tamil Nadu, India. A voucher specimen (MSU/PHAR/HER-140) has been preserved in the Herbarium of the Department of Pharmaceutical Chemistry, Manonmaniam Sundaranar University, Tirunelveli - 627 012 .

\section{Extraction of plant material}

The leaves of Desmodium gyrans DC were dried under shade and powdered. The dried powder (500 g) was successively extracted using petroleum ether $\left(40-60^{\circ} \mathrm{C}\right)$, benzene, chloroform, ethanol and water by using a Soxhlet apparatus. The last trace of the solvent was removed under reduced pressure by rotary evaporator. The dried crude ethanolic extract has been used for the study [22]

\section{Animals}

Wistar albino rats either sex weighing between $180 \mathrm{~g}$ and $200 \mathrm{~g}$ were selected for the acute toxicity and wound healing activity studies. The study was approved by the Institutional Ethics Committee for animal experimentation $\mathrm{KMCH}$ college of Pharmacy, Coimbatore. The animals were stabilized for 1 week. They were maintained in standard conditions at room temperature, $60 \pm 5 \%$ relative humidity and 12 $\mathrm{h}$ light dark cycle. They were given standard pellet diet supplied by Hindustan Lever Co., Mumbai and water ad libitum throughout the course of the study.

\section{Acute toxicity studies}

Albino rats of either sex received ethanolic extract of Desmodium gyrans leaves starting at $2 \mathrm{~g} / \mathrm{kg}$ bw orally by gavage. The animals were observed for toxic symptoms continuously for the first $4 \mathrm{~h}$ after dosing.
Finally, the number of survivors was noted after $24 \mathrm{~h}$ and these animals were then maintained for further 13 days with observations made daily [23]

\section{Selection of doses}

For assessment of excision wound healing activity ethanolic extract was formulated in ointment by using simple ointment BP as base. $2 \%(\mathrm{w} / \mathrm{w})$ ointment was applied where $2 \mathrm{~g}$ of the ethanolic extract was incorporated in $100 \mathrm{~g}$ of simple ointment base BP. $0.2 \mathrm{~g}$ of each of the extract ointment and ciphadin ointment was applied once daily to treat different groups of animals, respectively.

For the assessment of wound healing activity by dead space wound model, three dose levels were chosen in such a way that, middle dose was approximately one-tenth of the maximum dose during acute toxicity studies, and a low dose, which was $50 \%$ of the one tenth dose, and a high dose, which was twice that of one-tenth dose $(100 \mathrm{mg} / \mathrm{kg} \mathrm{bw}$, $200 \mathrm{mg} / \mathrm{kg}$ bw and $400 \mathrm{mg} / \mathrm{kg} \mathrm{bw}$ ).

\section{In Vivo Wound healing activity}

Excision wound model: The animals were divided into three groups of six rats each (Table 1)

Group I served as control

Group II served as standard (ciphadin) treated with ointment topically

Group III served as test treated with Desmodium gyrans ethanol extract ointment

All animals in each group were anaesthetized by the open mask method with anaesthetic ether before wound creation. An excision

\begin{tabular}{|c|c|c|c|c|c|c|}
\hline \multirow[b]{2}{*}{ Days } & \multicolumn{2}{|c|}{ Control } & \multicolumn{2}{|c|}{ Standard (Ciphadin) } & \multicolumn{2}{|c|}{ Ethanol extract } \\
\hline & Wound area & $\%$ of wound contraction & Wound area & $\%$ of wound contraction & Wound area & $\begin{array}{l}\% \text { of wound } \\
\text { contraction }\end{array}$ \\
\hline Oday & $535 \pm 18.3(0.0 \%)$ & - & $508 \pm 38.5(0.0 \%)$ & - & $520 \pm 34.3(0.0 \%)$ & - \\
\hline 3day & $508 \pm 21.0(5.04 \%)$ & 94.9 & $450 \pm 34.4(11.42 \%)$ & 88.5 & $406 \pm 29.1(21.93 \%)$ & 78.0 \\
\hline 5day & $460 \pm 17.6(14.01 \%)$ & 85.9 & $320 \pm 28.8^{a}(37.00 \%)$ & 62.9 & $326 \pm 32.8^{\mathrm{a}}(37.31 \%)$ & 62.6 \\
\hline 7 day & $400 \pm 12.0(25.23 \%)$ & 74.7 & $264 \pm 31.5^{\mathrm{a}}(48.03 \%)$ & 51.9 & $194 \pm 31.0^{\mathrm{b}}(62.69 \%)$ & 37.3 \\
\hline 9day & $369 \pm 16.5(31.02 \%)$ & 68.9 & $186 \pm 25.2^{\mathrm{a}}(63.38 \%)$ & 36.6 & $82 \pm 35.4^{b}(84.23 \%)$ & 15.7 \\
\hline 11day & $309 \pm 14.5(42.24 \%)$ & 57.7 & $104 \pm 22.0^{\mathrm{b}}(79.52 \%)$ & 20.4 & $48 \pm 28.2^{b}(90.77 \%)$ & 9.2 \\
\hline 13day & $278 \pm 13.3(48.03 \%)$ & 51.9 & $80 \pm 18.4^{\mathrm{b}}(84.25 \%)$ & 15.7 & $16 \pm 10.4^{\mathrm{b}}(96.92 \%)$ & 3.0 \\
\hline 15day & $208 \pm 12.7(61.12 \%)$ & 38.8 & $46 \pm 21.8^{b}(90.94 \%)$ & 9.0 & $6 \pm 8.1^{\mathrm{b}}(98.85 \%)$ & 1.1 \\
\hline 17day & $172 \pm 10.2(67.85 \%)$ & 32.1 & $8 \pm 7.1^{\mathrm{b}}(98.42 \%)$ & 1.5 & $0.0^{\mathrm{b}}(100 \%)$ & 0 \\
\hline 19day & $166.12 .0(68.97 \%)$ & 31.0 & $0.0^{\mathrm{b}}(100 \%)$ & 0 & $0.0^{\mathrm{b}}(100 \%)$ & 0 \\
\hline Epithelization time (days) & \multicolumn{2}{|c|}{23} & \multicolumn{2}{|c|}{17} & \multicolumn{2}{|c|}{15} \\
\hline
\end{tabular}

Values are mean $\pm \operatorname{SEM}(n=6)$

$P$ values vs. respective control by Dunnet's t-test: ${ }^{a} p<0.01,{ }^{b} p<0.001$.

Table 1: Effect of the ethanol extract of the leaves of Desmodium gyrans and standard ointment on percentage wound contraction and epithelialization period of excision wound model in rats.

\begin{tabular}{|c|c|c|c|c|c|}
\hline \multirow{2}{*}{ Groups } & \multirow{2}{*}{ Doses } & \multicolumn{2}{|c|}{ Granuloma (mg) } & \multirow{2}{*}{ Granuloma breaking strength (g) } & \multirow{2}{*}{ Hydroxyproline content $(\mu \mathrm{g} / \mathrm{ml})$} \\
\hline & & Wet wt & Dry wt & & \\
\hline Control & - & $68.1 \pm 8.9$ & $24.9 \pm 3.4$ & $256.8 \pm 2.15$ & $1.868 \pm 0.03$ \\
\hline Standard (Ciphadin) & 50 mg/animal & $146.4 \pm 4.43^{*}$ & $54.9 \pm 3.19^{*}$ & $347.8 \pm 3.8^{*}$ & $5.267 \pm 0.02^{*}$ \\
\hline Desmodium gyrans ethanol extract & $100 \mathrm{mg} / \mathrm{kg} \mathrm{bw}$ & $73 \pm 4.16^{*}$ & $27.67 \pm 2.33^{*}$ & $283.3 \pm 2.7^{*}$ & $3.825 \pm 0.04^{*}$ \\
\hline Desmodium gyrans ethanol extract & $200 \mathrm{mg} / \mathrm{kg} \mathrm{bw}$ & $91.33 \pm 2.33^{*}$ & $34.33 \pm 0.88^{*}$ & $335.0 \pm 4.46^{*}$ & $4.847 \pm 0.04^{*}$ \\
\hline Desmodium gyrans ethanol extract & $400 \mathrm{mg} / \mathrm{kg} \mathrm{bw}$ & $92.67 \pm 2.33^{*}$ & $37 \pm 2.65^{*}$ & $383.2 \pm 3.34^{*}$ & $5.143 \pm 0.03^{*}$ \\
\hline
\end{tabular}

Values are mean \pm SEM $(n=6)$

$P$ values vs. respective control by Dunnet's t-test: ${ }^{*} p<0.05$ 
Citation: Gopalakrishnan S, Rajameena R (2012) Evaluation of Ethanolic Extract of Desmodium Gyrans DC Leaves on Wound Healing Activity in Rats. Pharmaceut Anal Acta 3:169. doi:10.4172/2153-2435.1000169

Page 3 of 5

wound was inflicted by cutting away a $500 \mathrm{~mm}^{2}$ full thickness of skin from a predetermined area, the wound was left undressed to the open environment and the wound contraction and wound closure time was monitored. Wound contraction was measured as percentage contraction in each 2 days after wound formation from the healed wound, a specimen sample of tissue was isolated from each rat for histopathological examination [24].

Dead space wound model: The animals were divided into five groups of six rats each and kept in separate cages (Table 2)

Group I served as control

Group II served as standard (ciphadin) treated with ointment topically

Group III was treated with ethanolic extract of Desmodium gyrans DC (100 mg/kg bw)

Group IV was treated with ethanolic extract of Desmodium gyrans DC $(200 \mathrm{mg} / \mathrm{kg} \mathrm{bw})$

Group V was treated with ethanolic extract of Desmodium gyrans DC $(400 \mathrm{mg} / \mathrm{kg} \mathrm{bw})$

The model was used for the study of granuloma tissue. Animals were anaesthetized by light ether and wound was made by implantation of two polypropylene tubes $(2.0 \times 0.5 \mathrm{~cm})$ one on either side, in the lumber region on the dorsal surface in each animal on the ninth postwounding day, granuloma tissue formed on an implanted tube was dissected out carefully. Granuloma tissue from one tube was dried $\left(60^{\circ} \mathrm{C}\right)$ and stored in $10 \%$ formalin for the biochemical parameters and histopathological study. While the other part of granuloma tissue was used for determination of tensile strength $[25,26]$.

\section{Wound healing evaluation parameters}

Wound contraction and epithelialization time: An excision wound margin was traced after wound creation by using transparent paper and area measured by graph paper. Wound contraction was measured in each 2 days interval, until complete wound healing and expressed in percentage of healing wound area. The epithelialization time was measured from initial day [27] (Figure 1).

Measurement of tensile strength: Tensile strength is the resistance to breaking under tension. It indicates how much the repaired tissue resists to breaking under tension and may indicate in part the quality of repaired tissue. Sutures were removed on the day 9 after wound creation and the tensile strength was measured with the help of tensiometer, which is based on method of Kuwano [27]. In this method, wound breaking strength was measured as the weight of water at the time of wound breaking per area of the specimen.

Histopathological studies: Wound tissue specimens from control, test and standard groups were taken after complete healing excision and dead space wound and after usual processing. $6 \mathrm{~mm}$ thick sections were cut and stained with haematoxylin and eosin [28]. Sections were qualitatively assessed under the light microscope and observed in respect of fibroblast proliferation, collagen formation, angiogenesis, epithelialization, and hydroxy proline estimation. Tissues were dried in a hot air oven at $60-70^{\circ} \mathrm{C}$ to constant weight and were hydrolysed in $6 \mathrm{~N}$ $\mathrm{HCl}$ at $130^{\circ} \mathrm{C}$ for $4 \mathrm{~h}$ in sealed tubes. The hydrolysate was neutralized to $\mathrm{pH} 7.0$ and was subjected to chloramines-T oxidation for $20 \mathrm{~min}$. the reaction was determinated by addition of $0.4 \mathrm{M}$ perchloric acid and colour was developed with the help of Ehrlich reagent at $60^{\circ} \mathrm{C}$ [29] and measured at $557 \mathrm{~nm}$ using a spectrophotometer.
Statistical analysis: Treated group was compared with the control group. The results were analysed statistically using Dunnet's ' $t$ '-test to identify the differences between the treated and control groups. The data were considered significant at $p<0.01$.

\section{Results}

\section{Wound contraction}

The percentage wound contraction was determined using the following formula:-

$$
\text { presentage would contraction }=\frac{\text { Healed area }}{\text { Total wound area }} \times 100
$$

Wound area was measured by tracing the wound margin using a transparent paper in each 2 days interval and healed area calculated by subtracting from the original wound area. On day 15 , the wound contraction of standard and ethanol extract ointment treated groups
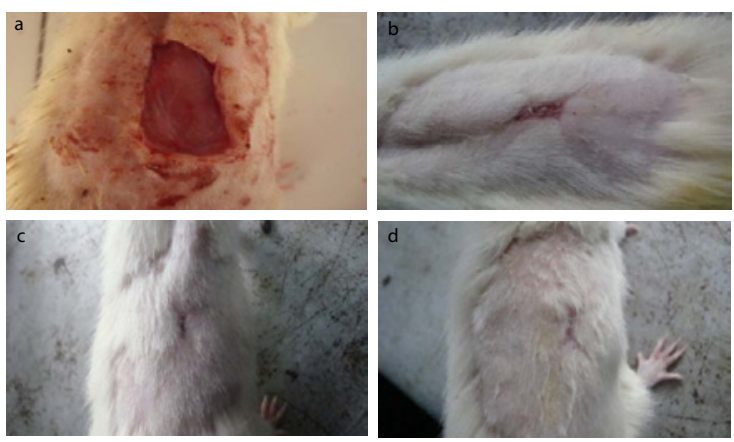

Figure 1: Albino rats dorsal wound area photographed at 17 days after application of the ethanolic extract of Desmodium gyrans leaves by Excision model. a) Excision wound on the 0 day b) wound healed treatment (control) c) wound healed treatment standard d) wound healed treatment (ethanol extract $2 \% \mathrm{w} / \mathrm{w}$ ).
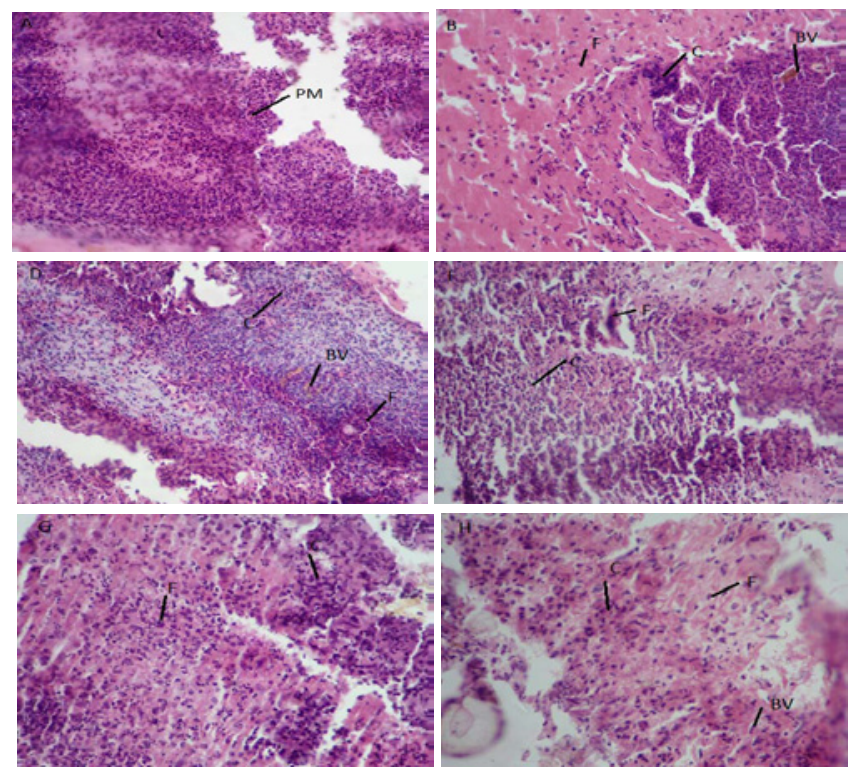

Figure 2: Photomicroscopic view of histopathological characteristics of 9-day-old wound tissue section by Excision and Dead space model (Hematoxylin and eosin $\times 40$ ). a) Wound tissue treated with control b) Wound tissue treated with standard c) Wound tissue treated with ethanol extract d) Dead space model with ethanol extract $(100 \mathrm{mg} / \mathrm{kg})$ e) Dead space model with ethanol extract $(200 \mathrm{mg} / \mathrm{kg}) \mathrm{f})$ ead space model with ethanol extract $(400 \mathrm{mg} / \mathrm{kg})$. 
was found to be significant $(p<0.01)$ in comparison to simple ointment base treated group. On day 17 ethanol extract ointment treated wound was completely healed while standard ointment treated group was also almost at complete healing stage, and simple ointment base treated group showed $67.85 \%$ healing. It was also observed that epithelialization period of treated and standard group were less in comparison to simple ointment base treated group (Table 1).

Effect of the ethanol extract of Desmodium gyrans and standard (ciphadin) ointment in wistar rats excision and dead space type of wounds showed significant healing as in epithelialization, collagenation (C), fibrablasts cells (F) and angiogenesis (BV).

\section{Tensile strength of dead space wound}

Tensile strength for the treated group on day 17 was found to be significant $(p<0.05)$ than control group as shown in Table 2.

\section{Hydroxy proline and granuloma weight}

Treated group showed significant increased hydroxy proline level when compared to that of the control group $(p<0.05)$ (Table 2). Granuloma weight of treated animal groups was found to be increased when compared with that of the control group.

\section{Discussion}

Wound healing process consists of different phases such as granulation, collagenation, collagen maturation and scar maturation which are concurrent but independent to each other. Hence in this study two different models were used to assess the effect of ethanolic extract of Desmodium gyrans on various phases.

The results showed that the ethanolic extract ointment possesses a definite prohealing action. In excision wound healing model the ethanolic extract of the leaves of Desmodium gyrans showed significant increase in percentage closure of excision wounds by enhanced epithelization significant increase, $(p<0.01)$ in tensile strength, granuloma tissue and hydroxy proline content, which was further supported by histopathological studies and gain in granuloma breaking strength. This indicated improved collagen maturation by increased cross linking. An increase in dry granuloma weight indicated higher protein content.

The preliminary phytochemical analysis of the alcoholic extract of the Desmodium gyrans leaves showed the presence of flavonoids, phenolic compounds, steroid and alkaloids. These phytochemical constituents may be responsible for the wound healing activity. The Desmodium plant extracts possessed a wide range of pharmacological properties, including improving cardiovascular and cerebrovascular functions and regulating immune system as well as anti-inflammatory, cytotoxic, antiparasitic, antidiabetic, antinephrolithic, antibacterial, and nootropic activites [30].

\section{Conclusion}

The study showed that the ethanol extract ointment of Desmodium gyrans effectively stimulates wound contraction, increases tensile strength of dead space wounds as compared to the control group. These findings justify the inclusion of this plant in the management of wound healing.

\section{Acknowledgement}

One of the authors, R. Rajameena thanks the Manonmaniam Sundaranar University, Tirunelveli for the University Stipendiary Research Fellowship (USRF) and Dr. A.Rajasekaran, Principal, KMCH college of Pharmacy, Coimbatore for providing facilities to carryout the pharmacological studies.

\section{References}

1. Howard Jones N (1985) A ClOMS ethical code for animal experimentation WHO chron 39: 51-56.

2. Aquino R, De Simone F, De Tommasi N, Piacente S, Pizza C (1995) Structure and biological activity of susquiterpene and diterpene. In: Hostettmann $\mathrm{K}$ Marston A, Maillard M, Hamburger M (Eds) Phytochemistry of plants used in Traditional medicine Oxford University Press NewYork 408

3. Abu Al-Basal M (2001) The influence of some local medicinal plant extract on skin wound healing activity evaluated by histological and ultra-structura studies. Ph.D Thesis University of Jordon, Amman, Jordann.

4. Rashed AN, Afifi FU, Disi AM (2003) Simple evaluation of the wound healing activity of a crude extract of Portulaca oleracea L. (growing in Jordon) in mus musculus JVI-1. J Ethnopharmacol 88: 131-136.

5. Cotran RS, Kumar V, Collins T (1997) Robbin's Pathological Basis of Disease $6^{\text {th }}$ ed, A Harcourt Publishing International Company, Singapore, 107-109.

6. Ulubelen A, Topcu G, Tan N, Olcal S, Johansson C, et al. (1995) Biologica activites of a Turkish medicinal plants Prangos platychlaena. J Ethanopharmaco 45: 193-197.

7. Hemmati AA, Mohammadian F (2000) An investigation into the effects of mucilage of Quince seeds on wound healing in rabbit. Journal of Herbs spices and Medicinal Plants 7:41-46.

8. Choi SW, Son BW, Son YS, Prak YI, Lee SK, et al. (2001) The wound healing effect of glycoprotein fraction isolated from Aloe vera. Br J Dermatol 145: 535 545

9. Bairy KL (2002) Wound healing potential of plant products. Journal of Natura Remedies 2: 11-20.

10. Mantle D, Gok MA, Lennard TW (2001) Adverse and beneficial effects of plan extract on skin and skin disorders. Adverse Drug React Toxicol Rev 20: 89-103.

11. Govindarajan R, Vijayakumar M, Rao CV, Shirwaikar A, Kumar S, et al (2007) Anti-inflammatory and antioxidant activities of Desmodium gangetieum fractions in Carrageenan-induced inflamed rats. Phytother Res 21: 975-979.

12. Rathi A, Rao ChV, Ravishankar B, De S, Mehrotra S (2004) Anti-inflammatory and anti-nociceptive activity of the water decoction Desmodium gangeticum. Ethnopharmacol 95: 259-263.

13. Joshi H, Parle M (2006) Antiamnesic effects of Desmodium gangeticum in mice. Yakugaku Zasshi 126: 795-804.

14. Kurian GA, Philip S, Varghese T (2005) Effect of aqueous extract of the Desmodium gangeticum DC root in the severity of myocardial infarction. $J$ Ethanopharmacol 97: 457-461.

15. Dharmani P, Mishra PK, Maurya R, Chauhan VS, Palit G (2005) Desmodium gangeticum: a potent anti-ulcer agent. Indian J Exp Biol 43: 517-521.

16. Purushothaman KK, Kishore VM, Narayanaswami V, Connolly JD (1971) The structure and stereochemistry of gangetin, a new pterocarpan from Desmodium gangeticum (Leguminosae). J Chem Soc C 20: 2420-2422.

17. Mishra PK, Singh N, Ahmad G, Dube A, Maurya R (2005) Glycolipids and other constituents from Desmodium gangeticum with antileishmanial and immunomodulatory activites. Bioorg Med Chem Lett 15: 4543-4546.

18. Chandrasekharan S, Balakrishna K, Connolly JD (1975) Gangetinin and desmodin two minor pterocarpanoids of Desmodium gangeticum. Phytochem 14.

19. Govindarajan R, Vijayakumar M, Shirwaikar A, Rawat AK, Mehrotra S, et al (2006) Antioxidant activity of Desmodium gangeticum and its phenolics in arthritic rats. Acta Pharm 56: 489-496.

20. Lai SC, Ho YL, Huang SC, Huang TH, Lai ZR, et al. (2010) Antioxidant and antiproliferative activities of Desmodium triflorum (L) DC. Am J Chin Med 38 329-342.

21. Lai SC, Peng WH, Huang SC, Ho YL, Huang TH, et al. (2009) Analgesic and anti-inflammatory activites of methanol extract from Desmodium triflorum DC in mice. Am J Chin Med 37: 573-588.

22. Trease GE, Evans WC (1987) A Text Book of Pharmacognosy, EISB Baillare Tindal, Oxford, 1055

23. Adeneye AA, Ajagbonna OP, Adeleke TI, Bello SO (2006) Preliminary toxicity 
Citation: Gopalakrishnan S, Rajameena R (2012) Evaluation of Ethanolic Extract of Desmodium Gyrans DC Leaves on Wound Healing Activity in Rats. Pharmaceut Anal Acta 3:169. doi:10.4172/2153-2435.1000169

Page 5 of 5

and phytochemical studies of the stem bark aqueous extract of Musanga cecropioides in rats. J Ethanopharmacol 105: 374-379

24. Taranalli AD, Tipare SV, Kumar S, Torgal SS (2004) Wound healing activity of Oxalis corniculata whole plant extract in rats. Indian J Pharm Sci 66: 444-446.

25. Shirwaikar A, Jahagirdar S, Udupa AL (2003) Wound healing activity of Desmodium triquetrum leaves. Indian J Pharm Sci 65: 461-464.

26. Patil MB, Jalapure JS, Ashraaf A (2001) Preliminary phytochemical investigation and wound healing activity of the leaves of Argemone maxicana Linn. (Papaveraceae) Indian Drugs 36: 288-293.
27. Kuwano H, Yano K, Ohano S, Ikebe M, Kitampura K, et al. (1994) Dipyridamole inhibits early wound healing in rats skin incisions. J Surg Res 56: 267-270.

28. Mc Manus JFA, Mowry RW (1965) Staining Methods Histologic and Histochemical, Harper\&Row/ Evanston, NewYork/ London.

29. Woessner JF (1961) The determination of hydroxyproline in tissue and protein samples containing small proportions of this imino acid. Biophys 93: 440-447.

30. Ma X, Zheng C, Hu C, Rahman K, Qin L (2011) The genus Desmodium (Fabaceae)-traditional uses in Chinese medicine, phytochemistry and pharmacology. J Ethnopharmacol 138: 314-332. 